\title{
Simulation of a Tubular Solid Oxide Fuel Cell Stack Operating on Biomass Syngas Using Aspen Plus
}

\author{
Wayne Doherty \\ Technological University Dublin, wayne.doherty@tudublin.ie \\ Anthony Reynolds \\ Technological University Dublin, anthony.reynolds@tudublin.ie \\ David Kennedy \\ Technological University Dublin, david.kennedy@tudublin.ie
}

Follow this and additional works at: https://arrow.tudublin.ie/engschmecart

Part of the Energy Systems Commons, and the Thermodynamics Commons

\section{Recommended Citation}

Doherty, W., Reynolds, A., Kennedy, D., : Simulation of a Tubular Solid Oxide Fuel Cell Stack Operating on Biomass Syngas Using Aspen Plus. Journal of The Electrochemical Society 2010;157:B975-B981. doi:10.1149/1.3205661

This Article is brought to you for free and open access by the School of Mechanical and Design Engineering at ARROW@TU Dublin. It has been accepted for inclusion in Articles by an authorized administrator of ARROW@TU Dublin. For more information, please contact arrow.admin@tudublin.ie, aisling.coyne@tudublin.ie, gerard.connolly@tudublin.ie.

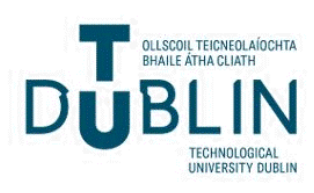




\title{
Simulation of a Tubular Solid Oxide Fuel Cell Stack Operating on Biomass Syngas Using Aspen Plus
}

\author{
Wayne Doherty, ${ }^{*, z}$ Anthony Reynolds, and David Kennedy
}

Department of Mechanical Engineering, Dublin Institute of Technology, Dublin 1, Ireland

\begin{abstract}
A tubular solid oxide fuel cell stack was modeled, and its operation on biomass syngas was investigated. The objective of this work was to develop a computer simulation model of a biomass gasification-solid oxide fuel cell system capable of predicting performance under various operating conditions and using diverse fuels. The stack was modeled using Aspen Plus and considers ohmic, activation, and concentration losses. It was validated against published data for operation on natural gas. Operating parameters such as fuel and air utilization factor $\left(U_{\mathrm{f}}\right.$ and $U_{\mathrm{a}}$, respectively), current density $j$, and steam to carbon ratio (STCR) were varied and had significant influence. The model was run on wood and miscanthus syngas. The results indicated that there must be a trade-off between voltage, efficiency, and power with respect to $j$ and that the stack should be operated at a low STCR and a high $U_{\mathrm{f}}$. Also, the stack should be operated at a $U_{\mathrm{a}}$ of $\sim 20 \%$. Operation on biomass syngas was compared to natural gas operation and, as expected, performance degraded. Better stack performance was observed for wood syngas compared to miscanthus syngas. High efficiencies were predicted making these systems very promising. (C) 2010 The Electrochemical Society. [DOI: 10.1149/1.3407524] All rights reserved.
\end{abstract}

Manuscript submitted July 26, 2009; revised manuscript received February 19, 2010. Published May 5, 2010. This was Paper 1284 presented at the Vienna, Austria, Meeting of the Society, October 4-9, 2009.

As the contribution of renewable energy increases, biomass is likely to play an important role as it is among the most promising sources of renewable energy in the context of both environmental and energy security issues. Traditionally, energy is recovered from biomass through combustion at a low electrical efficiency (20$25 \%$ ). Biomass gasification systems offer much higher efficiencies thus making the fuel suitable for power generation. Biomass gasification is well suited for integration with high temperature fuel cells. Reported electrical efficiencies for biomass gasification-solid oxide fuel cell (BG-SOFC) systems range from 23-50\%. ${ }^{1}$ These systems offer highly efficient renewable energy and are modular in nature making them ideal for decentralized combined heat and power (CHP) applications, and as a result, have recently gained much attention. $^{2-10}$

Gasification occurs when a controlled amount of oxidant (pure oxygen, air, and/or steam) is reacted at high temperatures with available carbon in biomass or other carbonaceous material within a gasifier, producing a combustible gas. The combustible gas (syngas) is composed mainly of hydrogen $\left(\mathrm{H}_{2}\right)$, carbon monoxide $(\mathrm{CO})$, methane $\left(\mathrm{CH}_{4}\right)$, carbon dioxide $\left(\mathrm{CO}_{2}\right)$, water $\left(\mathrm{H}_{2} \mathrm{O}\right)$, and nitrogen $\left(\mathrm{N}_{2}\right)$ as well as small amounts of higher hydrocarbons. Air gasification produces a syngas with low heating value, around 4-7 MJ/m 3 higher heating value (HHV), while $\mathrm{O}_{2}$ and steam blown processes result in a syngas with a heating value in the range of $10-18 \mathrm{MJ} / \mathrm{m}^{3}$ HHV. ${ }^{11-13}$

SOFCs convert the chemical energy contained in a fuel gas directly to electrical energy via electrochemical reactions, making them a highly efficient energy conversion device. The tubular SOFC configuration is considered to be the most advanced and therefore was selected for this study. This technology was developed by Siemens Power Generation Incorporated (SPGI). These SOFCs can utilize a wide spectrum of fuels (natural gas, coal, and biomass syngas) due to their high operating temperature. CO-rich gases (i.e., biomass and coal syngas) are attractive and useful fuels for SOFCs exhibiting excellent power generation characteristics comparable to those for $\mathrm{H}_{2}$-based fuels. ${ }^{14}$ Various models have been developed to simulate tubular SOFC performance, many of them for operation on humidified $\mathrm{H}_{2}$ or natural gas. ${ }^{15-22}$ A review of SOFC models can be found in the literature. ${ }^{23}$

In this work, the operation and performance of a tubular SOFC stack on wood and miscanthus syngas were investigated. The objective of this work was to develop a computer simulation model of a

* Electrochemical Society Student Member.

${ }^{\mathrm{z}}$ E-mail: wayne.doherty@dit.ie
BG-SOFC CHP system capable of predicting system performance under various operating conditions and using diverse fuels. The SOFC stack model was developed using Aspen Plus. There is no built-in model that can represent an SOFC. It is common to develop a complete SOFC stack model in a programming language and link it to Aspen Plus as a subroutine. ${ }^{24}$ The subroutine must incorporate complex phenomena making them difficult and time consuming to develop and use. An alternative method proposed by Zhang et al., ${ }^{24}$ using existing Aspen Plus unit operation blocks with minimum requirements for linking of a subroutine, was used. The model is of equilibrium type and is based on Gibbs free energy minimization. The SOFC model performs heat and mass balances and considers the ohmic, activation, and concentration losses for the calculation of the operating voltage. Published data for the SPGI tubular SOFC stack operating on natural gas was used to validate the model. Sensitivity analyses were carried out to give insight into the influence of the main variables on the system. The model was run using many different fuels, syngas from wood, and also miscanthus gasification. For the wood case, data from the Güssing biomass gasification CHP plant was used. ${ }^{5}$ In the miscanthus syngas, data from a pilot scale circulating fluidized bed (CFB) gasifier was used. ${ }^{25}$

\section{Technology Description}

Biomass gasification systems. - The Güssing biomass CHP plant utilizes $8 \mathrm{MW}$ of wood chip fuel to produce $2 \mathrm{MW}_{\mathrm{e}}$ of electricity (grid connected) by a gas engine and $4.5 \mathrm{MW}_{\text {th }}$ of heat (district heating system). The wood syngas is produced using an atmospheric pressure dual fluidized bed steam gasifier. This type of gasifier operates with two separate zones: the combustion zone and the gasification zone. Char is combusted with air in the combustion zone and the heat is transferred to the gasification zone via circulating bed material. This heat drives the endothermic steam gasification reactions, which produce the syngas. A more detailed description of the process can be found in the literature. ${ }^{5,11}$ Efforts are ongoing to get an SOFC stack installed for testing at the Güssing plant. ${ }^{26}$ The following syngas composition was inputted to the SOFC stack model: $45.8 \% \mathrm{H}_{2}, 21.6 \% \mathrm{CO}, 10.0 \% \mathrm{CH}_{4}, 21.2 \% \mathrm{CO}_{2}, 1.4 \% \mathrm{~N}_{2}$ (vol \%, dry basis), and $25.7 \% \mathrm{H}_{2} \mathrm{O}$ (vol \%, wet basis). ${ }^{5}$

Numerous experiments have been carried out at the Delft University of Technology using a pilot scale $100 \mathrm{~kW}_{\text {th }}$ atmospheric pressure CFB gasifier. Experiments have been conducted using a wide range of fuels, including various woods, miscanthus, and straw. Reported syngas compositions from these experiments for miscanthus gasification have been used in this work: $13.65 \% \mathrm{H}_{2}$, $21.6 \% \mathrm{CO}, 7.5 \% \mathrm{CH}_{4}, 2.0 \% \mathrm{C}_{2} \mathrm{H}_{y}, 35.25 \% \mathrm{CO}_{2}, 13.0 \% \mathrm{~N}_{2}$ (vol \%, dry basis), ${ }^{25}$ and $40 \% \mathrm{H}_{2} \mathrm{O}$ (vol $\%$, wet basis). ${ }^{27}$ This miscanthus 


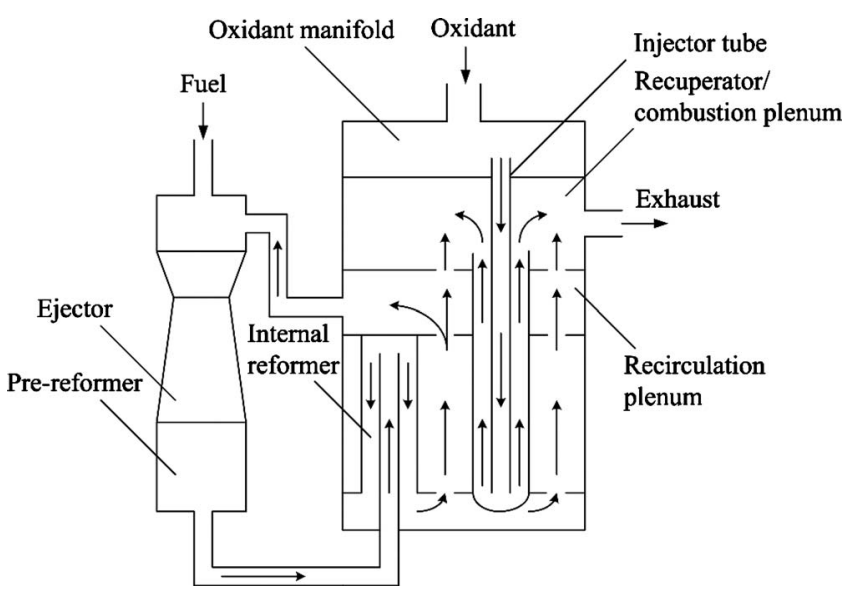

Figure 1. SOFC stack flow diagram.

syngas was produced using a steam-oxygen mixture as the fluidizing agent and plain sand as the bed material. To bring the syngas molar composition to $100 \%$, the difference was added to nitrogen $(7 \%)$ as it is inert and because its content was approximated due to measurement difficulties during the experiments. ${ }^{27}$

SOFC stack.- The $100 \mathrm{~kW}$ ac CHP tubular SOFC stack developed by SPGI was selected and modeled. This stack has been operated for over $36,000 \mathrm{~h}$ to date. ${ }^{28}$ Referring to Fig. 1, the operation of the stack is as follows: The oxidant stream is fed via injector tubes, placed centrally in each SOFC to the closed end of the cells. The oxidant then flows back through the annular space formed by the cathode surface and the injector tube to the open end. The oxidant is electrochemically reacted with the fuel supplied to the anode as it flows over the cathode surface. Cleaned fuel gas is supplied to the ejector where it is mixed with depleted fuel from the recirculation plenum. This anode recycle loop provides the steam and heat required for the steam reforming process. The mixed fuel then passes through the prereformers, which convert the higher hydrocarbons and a small portion of $\mathrm{CH}_{4}$ adiabatically to $\mathrm{H}_{2}$ and $\mathrm{CO}$. The partially reformed fuel enters the internal reformers, and using the heat generated by the exothermic electrochemical reactions occurring in the SOFC stack, it is reformed further. The fuel then flows along the anode surface from the closed end to the open end, parallel to the direction of the oxidant flow and is electrochemically oxidized, generating electricity and increasing the temperature of both streams. A portion of the depleted fuel is recycled, the quantity of which depends on the required steam to carbon ratio (STCR), and the remain- der is reacted with the depleted oxidant in the combustion plenum The generated heat serves to preheat the incoming oxidant stream in the injector tubes. Air is sufficiently preheated before reaching the outlet of the alumina tube, avoiding the destruction of the cell by a steep temperature gradient. ${ }^{20}$ The high temperature exhaust gas may then be utilized in a district heating system.

\section{SOFC Stack Model}

Model flowsheet description.- With reference to Fig. 2, the stream "SYNGAS" is fed to the "COMP1" block, the fuel compressor and its discharge pressure was set by assuming a pressure ratio: $P_{\text {fuel }} / P_{\text {SOFC }}=3 .{ }^{16}$ Syngas composition and thermodynamic condition were inputted; its mole flow rate depends on the specified stack power (or for variable power, it is set depending on the specified current density $j$ ). The syngas is preheated in the block "FUELHEAT" and its exit stream enters the "EJECTOR," where it is mixed with the recycled depleted fuel. The pressure of stream 4 is decreased to slightly above atmospheric pressure $\left(P_{\mathrm{SOFC}}\right)$ and is directed to "COOLER1." The two blocks COOLER1 and "PREREFOR" represent the stack prereformers. COOLER1 sets the prereforming temperature, which is calculated by a design specification, which varies the temperature of COOLER1 until the net heat duty of PREREFOR equals zero, i.e., adiabatic. The gas is cooled simulating the endothermicity of the steam reforming process. The following chemical reactions, assumed to reach equilibrium, were specified in the PREREFOR block

$$
\begin{gathered}
\text { Steam reforming: } \mathrm{C}_{n} \mathrm{H}_{m}+n \mathrm{H}_{2} \mathrm{O} \leftrightarrow(m / 2+n) \mathrm{H}_{2}+n \mathrm{CO} \\
\text { Water-gas shift: } \mathrm{CO}+\mathrm{H}_{2} \mathrm{O} \leftrightarrow \mathrm{CO}_{2}+\mathrm{H}_{2}
\end{gathered}
$$

The prereformed fuel (stream 6) enters "ANODE," where the remaining $\mathrm{CH}_{4}$ is reformed, $\mathrm{CO}$ is shifted, and $\mathrm{H}_{2}$ is oxidized. In an $\mathrm{SOFC}$, the following reactions occur

$$
\begin{aligned}
& \text { Cathode half reaction:0.5 } \mathrm{O}_{2}+2 \mathrm{e}^{-} \rightarrow \mathrm{O}^{2-} \\
& \text { Anode half reaction: } \mathrm{H}_{2}+\mathrm{O}^{2-} \rightarrow \mathrm{H}_{2} \mathrm{O}+2 \mathrm{e}^{-} \\
& \text {Overall reaction: } \mathrm{H}_{2}+0.5 \mathrm{O}_{2} \rightarrow \mathrm{H}_{2} \mathrm{O}
\end{aligned}
$$

The oxygen ion $\mathrm{O}^{2-}$ is the charge carrier in an SOFC. It is transported through the electrolyte to the anode side where it reacts with $\mathrm{H}_{2}$ to produce electrons $\mathrm{e}^{-}$. This cannot be modeled in Aspen Plus; therefore, the overall reaction was used in the simulation. Reactions 1,2 , and 5 were specified in the ANODE block, and it was assumed that they reach equilibrium at the operating temperature $\left(T_{\mathrm{op}}\right.$ $=1183.15 \mathrm{~K})$. The stream "AIR" is fed to "COMP2," the air compressor, and its discharge pressure was set to $P_{\mathrm{SOFC}}$. The air com-

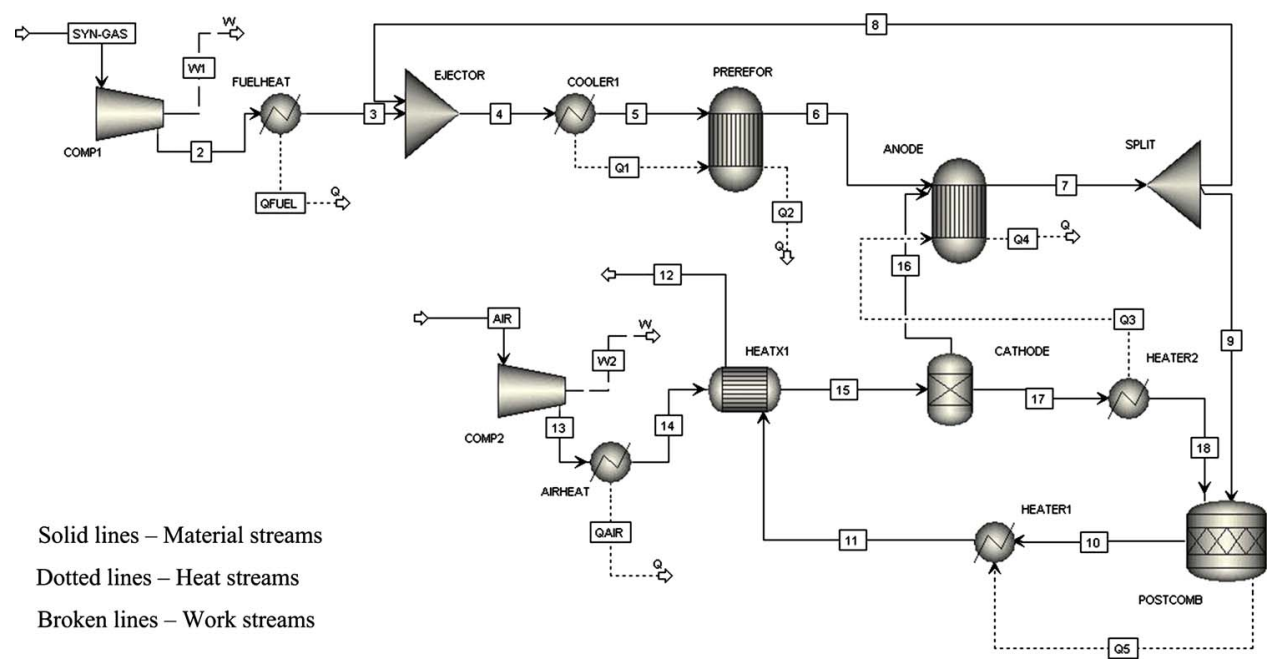

Figure 2. (Color online) Aspen Plus model flowsheet. 
position and thermodynamic condition were inputted, and the molar flow rate is set by varying the air flow until the air utilization factor $U_{\mathrm{a}}=0.167 .^{8,21}$ The compressed air is preheated in "AIRHEAT" and its exit stream enters "HEATX1" where it is preheated further by the hot combustion plenum products. Stream 15 enters the "CATHODE" block, whose function is to separate out the $\mathrm{O}_{2}$ required for the electrochemical reaction $n \mathrm{O}_{2 \text {,consumed }}$. The block $\mathrm{O}_{2}$ split fraction $\mathrm{O}_{2 \text {,split }}$ is set using the following equations

$$
\begin{gathered}
n \mathrm{H}_{2, \text { in }}=n \mathrm{H}_{2, \text { syngas }}+1\left(n \mathrm{CO}_{\text {syngas }}\right)+4\left(n \mathrm{CH}_{4, \text { syngas }}\right)+\ldots \\
U_{\mathrm{f}}=\frac{n \mathrm{H}_{2, \text { consumed }}}{n \mathrm{H}_{2, \text { in }}} \\
n \mathrm{O}_{2, \text { consumed }}=0.5 n \mathrm{H}_{2, \text { consumed }} \\
\mathrm{O}_{2, \text { split }}=\frac{n \mathrm{O}_{2, \text { consumed }}}{n \mathrm{O}_{2, \text { in }}}
\end{gathered}
$$

First, $n \mathrm{H}_{2 \text {,in }}$ is calculated, where $n \mathrm{H}_{2 \text {,syngas }}$ is the molar flow rate of $\mathrm{H}_{2}$ contained in SYNGAS, $1\left(n \mathrm{CO}_{\text {syngas }}\right)$ is the molar flow rate of $\mathrm{H}_{2}$ that could be produced from the $\mathrm{CO}$ in SYNGAS, and $4\left(n \mathrm{CH}_{4, \text { syngas }}\right)$ is the molar flow rate of $\mathrm{H}_{2}$ that could be produced from the $\mathrm{CH}_{4}$ in SYNGAS and the same applies to the higher hydrocarbons. Next, $n \mathrm{H}_{2 \text {,consumed }}$ is determined with the known $U_{\mathrm{f}}$.

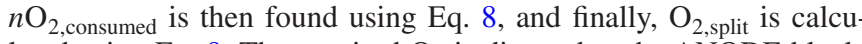
lated using Eq. 9. The required $\mathrm{O}_{2}$ is directed to the ANODE block. The temperature of the depleted air (stream 17) is brought up to $T_{\text {op }}$ in HEATER2. The heat is supplied by the electrochemical reaction, which was simulated by taking a heat stream (Q3) from HEATER2 to ANODE. Stream 7 enters the block "SPLIT," whose function is to split the stream into a recycle and a stream directed to the combustion plenum. The split fraction is determined by a specified STCR, defined as the molar ratio of steam to combustible carbon. Excess steam as well as increasing the concentration of $\mathrm{H}_{2}$ and $\mathrm{CO}_{2}$ inhibits the formation of carbon. Carbon deposition not only represents a loss in the system but results in the deactivation of catalysts and decreases the activity of the anode by clogging the active sites. The depleted fuel and oxidant are fed to "POSTCOMB" where complete combustion of the remaining fuel occurs. The heat generated is represented by the heat stream Q5, which is fed to "HEATER1," whose function is to set the combustion products temperature. Finally, the combustion products (stream 11) serve to preheat the incoming air in the HEATX1 block. The temperature of the stack exhaust (stream 12), which may be utilized in a district heating system, is also determined.

Voltage calculation.- The cell voltage was calculated by first applying the Nernst equation, Eq. 10 in Table I, and then subtracting the various losses, including ohmic, activation, and concentration

Table I. Voltage calculation equations.

Reversible Nernst voltage

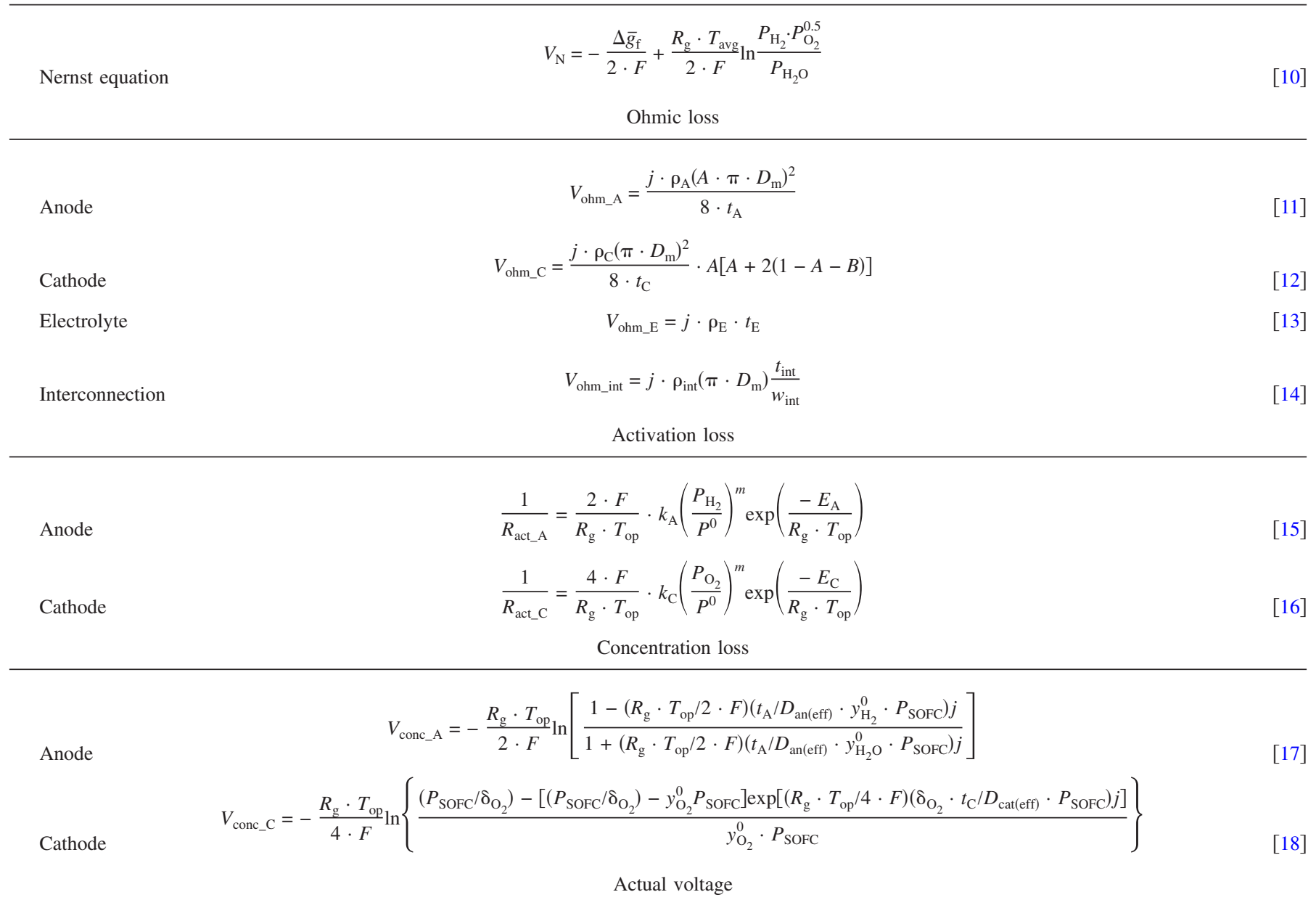

$$
V=V_{\mathrm{N}}-\left(V_{\text {ohm }}+V_{\text {act }}+V_{\text {conc }}\right)
$$




\begin{tabular}{|c|c|}
\hline \multicolumn{2}{|c|}{ Geometry parameters ${ }^{17,34,35}$} \\
\hline Cell length/outer diameter (m) & $1.5 / 0.022$ \\
\hline Anode thickness $t_{\mathrm{A}}(\mathrm{m})$ & 0.0001 \\
\hline Cathode thickness $t_{\mathrm{C}}(\mathrm{m})$ & 0.0022 \\
\hline Electrolyte thickness $t_{\mathrm{E}}(\mathrm{m})$ & 0.00004 \\
\hline Interconnection thickness $t_{\text {int }}(\mathrm{m})$ & 0.000085 \\
\hline Interconnection width $w_{\text {int }}(\mathrm{m})$ & 0.009 \\
\hline \multicolumn{2}{|c|}{ Material properties } \\
\hline Anode resistivity $\rho_{\mathrm{A}}(\Omega \mathrm{m})^{15}$ & $2.98 \times 10^{-5} \exp \left(-1392 / T_{00}\right)$ \\
\hline Cathode resistivity $\rho_{\mathrm{C}}(\Omega \mathrm{m}){ }^{15}$ & $8.114 \times 10^{-5} \exp \left(600 / T_{\text {op }}\right)$ \\
\hline Electrolyte resistivity $\rho_{\mathrm{E}}(\Omega \mathrm{m})^{15}$ & $2.94 \times 10^{-5} \exp \left(10350 / T_{\mathrm{op}}\right)$ \\
\hline \multicolumn{2}{|l|}{ Ohmic $\operatorname{loss}^{29}$} \\
\hline$A / B$ & $0.804 / 0.13$ \\
\hline \multicolumn{2}{|l|}{ Activation loss ${ }^{36}$} \\
\hline Pre-exponential factor $k_{\mathrm{A}}\left(\mathrm{A} / \mathrm{m}^{2}\right)$ & $2.13 \times 10^{8}$ \\
\hline Pre-exponential factor $k_{\mathrm{C}}\left(\mathrm{A} / \mathrm{m}^{2}\right)$ & $1.49 \times 10^{10}$ \\
\hline Slope $m$ & 0.25 \\
\hline Activation energy $E_{\mathrm{A}} / E_{\mathrm{C}}(\mathrm{J} / \mathrm{mol})$ & $110000 / 160000$ \\
\hline \multicolumn{2}{|l|}{ Concentration loss } \\
\hline Electrode pore radius $r(\mathrm{~m})^{37}$ & $5 \times 10^{-7}$ \\
\hline Electrode porosity $\varepsilon /$ tortuosity $\xi^{38}$ & $0.5 / 5.9$ \\
\hline
\end{tabular}

losses. $\Delta \bar{g}_{\mathrm{f}}$ is the molar Gibbs free energy of formation $(\mathrm{J} / \mathrm{mol})$ at standard pressure (1 bar), 2 represents the number of electrons produced per mole of $\mathrm{H}_{2}$ fuel reacted, $F$ is the Faraday constant $(\mathrm{C} /$ $\mathrm{mol}), T_{\text {avg }}$ is the average temperature between the SOFC inlet and outlet streams $(\mathrm{K}), R_{\mathrm{g}}$ is the molar gas constant $(\mathrm{J} / \mathrm{mol} \mathrm{K})$, and $P_{\mathrm{i}}$ is the partial pressure (bar) of gaseous component $i$. The partial pressures were taken as average values of the anode and cathode inlet and outlet streams. The gas composition changes along the length of the SOFC anode and cathode, and thus, the Nernst voltage and current vary with axial direction; the zero-dimensional model developed predicts the outlet gas composition, hence, the reason for using the average partial pressure values.

The ohmic loss, which is the voltage loss due to the resistance to electron flow through the electrodes and interconnection and the resistance to ion flow through the electrolyte, was calculated using Eq. $11-14{ }^{29}$ These equations have been used in many studies ${ }^{6,710,29-33}$ to simulate the ohmic loss for SPGI tubular SOFC systems. In addition, the operating cell voltage predicted by Song et al. $^{29}$ agrees very well with published SPGI data. The equations take into account realistic electron/ion paths. The angle related to the extent of electrical contact is $A \pi$ radians, while the angle $B \pi$ radians is related to the interconnection. The resistivity terms $\left(\rho_{\mathrm{A}}, \rho_{\mathrm{C}}, \rho_{\mathrm{E}}\right.$, and $\rho_{\text {int }}$ ) were determined using the temperature-dependent relations proposed by Bessette et al. ${ }^{15}$ given in Table II. $D_{\mathrm{m}}$ is the mean diameter of the cell $(\mathrm{m})$, calculated from the geometry parameters given in Table II, the $t$ terms represent cell component thickness (m), and $w_{\text {int }}$ is the interconnection width $(\mathrm{m})$. Interface resistances (contact resistances) were neglected. The ohmic loss is especially important for tubular SOFCs as it is the dominant loss due to long current flow paths.

The activation loss due to the slow or sluggish kinetics of the electrochemical reaction was determined using semiempirical correlations, Eq. 15 and $16 .^{36}$ The $R_{\text {act }}$ terms represent specific resistances $\left(\Omega \mathrm{m}^{2}\right)$ at both the anode and the cathode. The activation voltage loss $V_{\text {act }}$ was evaluated by multiplying the specific resistance terms by $j\left(\mathrm{~A} / \mathrm{m}^{2}\right)$. The pre-exponential factors $k_{\mathrm{A}}$ and $k_{\mathrm{C}}$ determined experimentally are listed in Table II. The partial pressures $P_{\mathrm{i}}$ (bar) were taken as average values of the anode and cathode inlet and outlet streams. $P^{0}$ is a reference pressure and was taken as 1 bar; the influence of partial pressure is accounted for by the slope $m$. The $E$ terms are activation energies and are listed in Table II. The activation voltage loss is less significant in SOFCs compared to other fuel cells due to the high operating temperature.

The concentration loss due to mass transfer limitations in the porous electrodes was modeled using Eq. 17 and $18 .^{37}$ Equations 17 and 18 were derived using Fick's law of diffusion with both ordinary and Knudsen diffusion considered. Both types of diffusion were accounted for by calculating effective diffusion coefficients for the anode and cathode $\left(D_{\text {an(eff) }}\right.$ and $\left.D_{\text {cat(eff })}\right)$. The explanation of the methods for calculating diffusion coefficients is beyond the scope of this paper. Fuller et al.'s method ${ }^{39}$ was applied to determine the ordinary binary diffusion coefficients, and the method reported by Chan et al. ${ }^{37}$ was used to calculate the Knudsen diffusion coefficients and the overall effective diffusion coefficients. The anode and cathode effective diffusion coefficients and $\delta_{\mathrm{O}_{2}}$ were calculated using the equations reported by Chan et al. ${ }^{37}$ The $y_{\mathrm{i}}^{0}$ terms in Eq. 17 and 18 are the gas molar fractions in the bulk flow, taken as the average values of the anode and cathode inlet and outlet streams. This loss is low unless the current density is high and the fuel and air concentrations are low, caused by high utilizations. Costamagna and Honegger ${ }^{40}$ have shown that at high fuel utilization anodic polarization increases due to both activation effects and diffusion limitations. Under these conditions, the limiting current may be reached reducing the fuel cell voltage to very low levels.

Finally, the actual voltage $V$ was calculated using Eq. 19, which is simply the Nernst voltage less the sum of the voltage losses. The voltage calculations were carried out using a design specification, which varies the input fuel flow rate until the dc power $\left(P_{\text {el,dc }}\right.$ $=\mathrm{VI}$ ) equals a specified value (base case of $120 \mathrm{~kW}$ ). However, for known current $I$, as was the case for the current density sensitivity analysis, a calculator block sets the input fuel flow using

$$
\begin{gathered}
n \mathrm{H}_{2, \text { in }}=\frac{I}{2 \mathrm{FU}_{\mathrm{f}}} \cdot \frac{3600}{1000} \\
n \text { fuel }_{\text {in }}=\frac{n \mathrm{H}_{2, \text { in }}}{y \mathrm{H}_{2}+y \mathrm{CO}+4 y \mathrm{CH}_{4}+\ldots}
\end{gathered}
$$

where $n$ fuel $_{\text {in }}$ is the input fuel flow $(\mathrm{kmol} / \mathrm{s})$ and $y_{\mathrm{i}}$ is the molar fraction of gaseous component $i$ in the input fuel. The voltage and dc power are then calculated. In both cases, the gross and net ac efficiencies [lower heating value (LHV) basis] are determined. The gross ac efficiency is defined as

$$
\eta_{\mathrm{el}, \mathrm{gross}}=\frac{P_{\mathrm{el}, \mathrm{ac}}}{n \text { fuel }_{\text {in }} \cdot \mathrm{LHV}_{\text {fuel }}}
$$

where $P_{\text {el,ac }}$ is the ac power $(\mathrm{kW}), n$ fuel $_{\text {in }}$ is the molar flow rate of input fuel $(\mathrm{kmol} / \mathrm{s})$, and $\mathrm{LHV}_{\text {fuel }}$ is the lower heating value of the input fuel $(\mathrm{kJ} / \mathrm{kmol})$. The net ac efficiency is defined as

$$
\eta_{\text {el, net }}=\frac{P_{\text {el,ac }}-P_{\text {comp }}}{n \text { fuel }_{\text {in }} \cdot \mathrm{LHV}_{\text {fuel }}}
$$

where $P_{\text {comp }}$ is the electrical power requirement of the fuel and air compressors $(\mathrm{kW})$. The procedure for implementing the aforementioned equations in Aspen Plus was as follows: In the design specification or calculator block, the variables required for the calculations were defined. Then, Fortran code was written; the constants were inputted and the equations were entered. When the user runs the model, the defined variables are accessed and plugged into the equations along with the constants and the results are outputted on the Aspen Plus control panel screen.

Model validation.- Validation of the model against published data for the SPGI $100 \mathrm{~kW}$ CHP SOFC stack operating on natural gas was carried out.

During validation runs, the model inputs were as follows: ${ }^{16,24}$

1. Natural gas composition (mol \%): $\mathrm{CH}_{4} 81.3 \%, \mathrm{C}_{2} \mathrm{H}_{6} 2.9 \%$, $\mathrm{C}_{3} \mathrm{H}_{8} 0.4 \%, \mathrm{C}_{4} \mathrm{H}_{10} 0.2 \%, \mathrm{~N}_{2} 14.3 \%$, and $\mathrm{CO}_{2} 0.9 \%$. 
Table III. Model validation.

\begin{tabular}{|c|c|c|}
\hline & Published data ${ }^{24}$ & Model results \\
\hline Voltage (V) & 0.7 & 0.683 \\
\hline Current density $\left(\mathrm{A} / \mathrm{m}^{2}\right)$ & 1780 & 1828.6 \\
\hline Pre-reforming temperature $\left({ }^{\circ} \mathrm{C}\right)$ & 536 & 535.1 \\
\hline Pre-reformer $\mathrm{CH}_{4}$ conversion fraction & 0.259 & 0.25 \\
\hline Cathode inlet temperature $\left({ }^{\circ} \mathrm{C}\right)$ & 821.32 & 823.7 \\
\hline Combustion products temperature $\left({ }^{\circ} \mathrm{C}\right)$ & 1012.35 & 1012.3 \\
\hline Stack exhaust temperature $\left({ }^{\circ} \mathrm{C}\right)$ & 833.85 & 833.7 \\
\hline Anode exhaust gas composition (mol \%) & $\mathrm{H}_{2} 11.6, \mathrm{CO} 7.4, \mathrm{H}_{2} \mathrm{O} 50.9, \mathrm{CO}_{2} 24.9, \mathrm{~N}_{2} 5.1$ & $\mathrm{H}_{2} 11.6, \mathrm{CO} 7.4, \mathrm{H}_{2} \mathrm{O} 50.9, \mathrm{CO}_{2} 24.9, \mathrm{~N}_{2} 5.1$ \\
\hline Cathode exhaust gas composition (mol \%) & $\mathrm{O}_{2} 17.7, \mathrm{~N}_{2} 82.3$ & $\mathrm{O}_{2} 17.7, \mathrm{~N}_{2} 82.3$ \\
\hline Stack exhaust gas composition (mol \%) & $\mathrm{H}_{2} \mathrm{O} 4.5, \mathrm{CO}_{2} 2.3, \mathrm{O}_{2} 15.9, \mathrm{~N}_{2} 77.3$ & $\mathrm{H}_{2} \mathrm{O} 4.5, \mathrm{CO}_{2} 2.3, \mathrm{O}_{2} 15.9, \mathrm{~N}_{2} 77.3$ \\
\hline Gross ac efficiency (LHV) (\%) & 52 & 51.28 \\
\hline Net ac efficiency (LHV) $(\%)$ & - & 49.15 \\
\hline
\end{tabular}
$\mathrm{Pa} / 3$.

2. Operating pressure $P_{\mathrm{SOFC}} /$ jector pressure ratio: 109,431

3. Operating/anode and cathode exhaust temperature $T_{\mathrm{op}}$ : $1183.15 \mathrm{~K}$.

4. Input air/fuel temperature: $630 / 200^{\circ} \mathrm{C}$

5. $U_{\mathrm{f}} / U_{\mathrm{a}} / \mathrm{STCR}: 0.85 / 0.19 / 1.8$.

6. dc power $P_{\mathrm{el}, \mathrm{dc}} / \mathrm{dc}$ to ac inverter efficiency: $120 \mathrm{~kW} / 92 \%$.

The model's results agree well with published data (see Table III). There is only a slight difference for voltage, current density, and efficiency. Zhang et al. ${ }^{24}$ used a very different method for calculating the voltage to the one applied in this work. They used semiempirical correlations developed using a reference polarization curve. For comparison, Campanari ${ }^{16}$ reports a voltage and current density of $0.69 \mathrm{~V}$ and $1800 \mathrm{~A} / \mathrm{m}^{2}$ and a net ac efficiency of $48.5 \%$. These results compare well with this work.

\section{Results and Discussion}

The model was run using the syngas compositions for wood and miscanthus fuel given in the Biomass gasification systems section of this paper. The input data was kept the same as that for validation with the following exceptions: fuel temperature $=300^{\circ} \mathrm{C}, U_{\mathrm{a}}$ $=0.167$, and STCR $=2.5 .{ }^{10}$ As expected, stack performance was better on natural gas than syngas. For the wood, gross and net efficiency reduced to 43 and $37.52 \%$, respectively, at $j=1828.6$ $\mathrm{A} / \mathrm{m}^{2}$. For the miscanthus, the gross and net efficiency reduced to 41.65 and $33.25 \%$, respectively. The drop in efficiency for the syngas fuel is attributed to the increased required fuel and air input, which is due to the lower quality of the fuel gas and also decreased

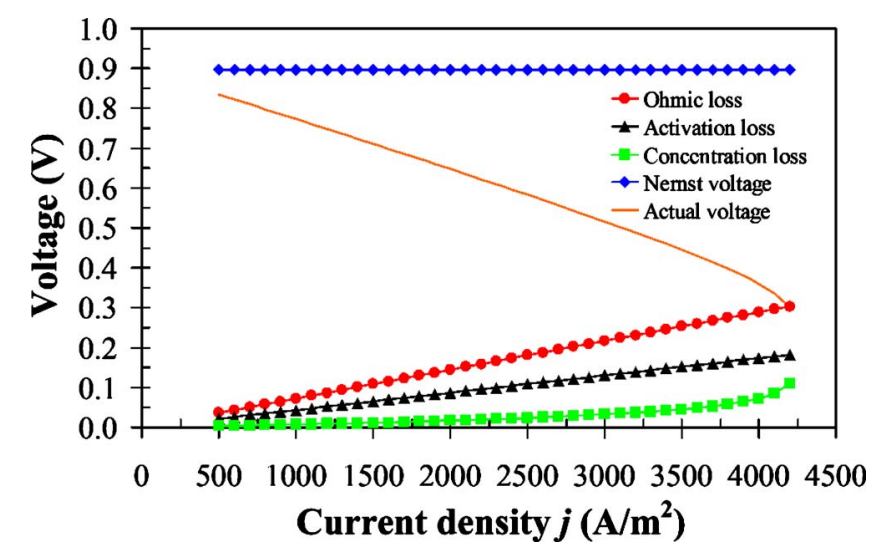

Figure 3. (Color online) SOFC voltage characteristics vs current density for wood syngas. power. Even with this performance decrease, the efficiency achieved is much higher than that of traditional biomass systems. The syngas exits the gasifier at $\sim 800^{\circ} \mathrm{C}$; its temperature at the entrance to the SOFC stack is determined by the gas cleaning system utilized. Gas cleaning systems typically operate at a temperature of $\sim 300^{\circ} \mathrm{C}$, which explains the assumed elevated fuel temperature. The high input air temperature $\left(630^{\circ} \mathrm{C}\right)$, which is the air temperature after the initial preheating step (block AIRHEAT Fig. 2), is achieved by utilizing the stack exhaust $\left(\sim 830^{\circ} \mathrm{C}\right.$ for base case).

Figure 3 displays the voltage characteristics of a single tubular SOFC fed with wood syngas. Very similar trends exist for the miscanthus syngas case; therefore, only the wood syngas results are presented. The miscanthus results are provided as supplementary material. ${ }^{41}$ The predicted voltage characteristics are consistent with the phenomena for tubular SOFCs: Nernst voltage $=\sim 0.9 \mathrm{~V}$, ohmic loss is dominant, activation loss is less significant in SOFCs due to high temperature, and concentration loss is the least significant but increases rapidly at high current density. Voltage characteristics were better for wood than miscanthus due to greater voltage losses in the miscanthus case. For example, at a typical $j$ of $1900 \mathrm{~A} / \mathrm{m}^{2}$, the cell voltage for wood syngas is $0.66 \mathrm{~V}$ and for miscanthus syngas it is lower at $0.637 \mathrm{~V}$.

Effect of current density.- Figure 4 shows that $j$ has a significant influence on the system. Similar trends were seen for both fuels; therefore, only the plot for the miscanthus syngas case is presented. The results for the wood syngas case are provided as supplementary material. ${ }^{41}$ Increasing $j$ lowers both the voltage and efficiency but increases power. Voltage is reduced as a result of increased losses, as shown in Fig. 3. Efficiency drops substantially $(\sim 35 \%$ for both fuels) due to higher parasitic power and energy

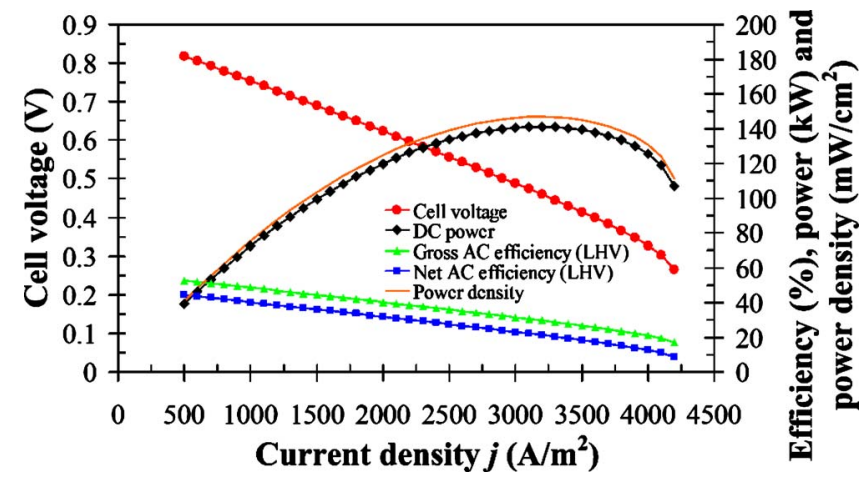

Figure 4. (Color online) Effect of current density on voltage, power, and efficiency for miscanthus syngas. 


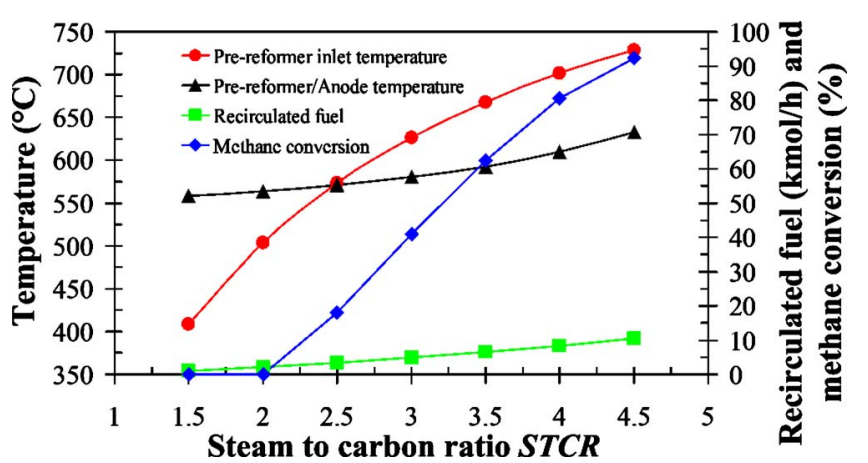

Figure 5. (Color online) Effect of STCR for wood syngas.

input. Power increases to a maximum and then decreases. Fuel cells are usually operated to the left of this point. It is desirable with regard to operating costs, to operate the stack at high voltage and efficiency; however, it is also desirable with regard to capital costs, to operate the stack at high power. Therefore, there must be a tradeoff between voltage, efficiency, and power. The stack operates with better performance on wood syngas compared to miscanthus syngas. The miscanthus syngas fed to the stack had a much lower $\mathrm{H}_{2}$ content and higher $\mathrm{CO}_{2}, \mathrm{H}_{2} \mathrm{O}$, and $\mathrm{N}_{2}$ contents than the wood syngas, which caused the reduction in performance. It also meant that a much higher fuel flow rate was required for the miscanthus case.

Effect of STCR.- The effects of changes in STCR are displayed in Fig. 5. Only the results for the wood syngas case are displayed; the same trends were seen for miscanthus syngas. The miscanthus results are provided as supplementary material. ${ }^{41}$ STCR has a substantial impact on the prereformer; the inlet temperature increases by approximately $320^{\circ} \mathrm{C}$ over the STCR range for both cases due to the recirculation of more high temperature depleted fuel. As a result, the anode temperature rises and causes greater $\mathrm{CH}_{4}$ conversion $(0-$
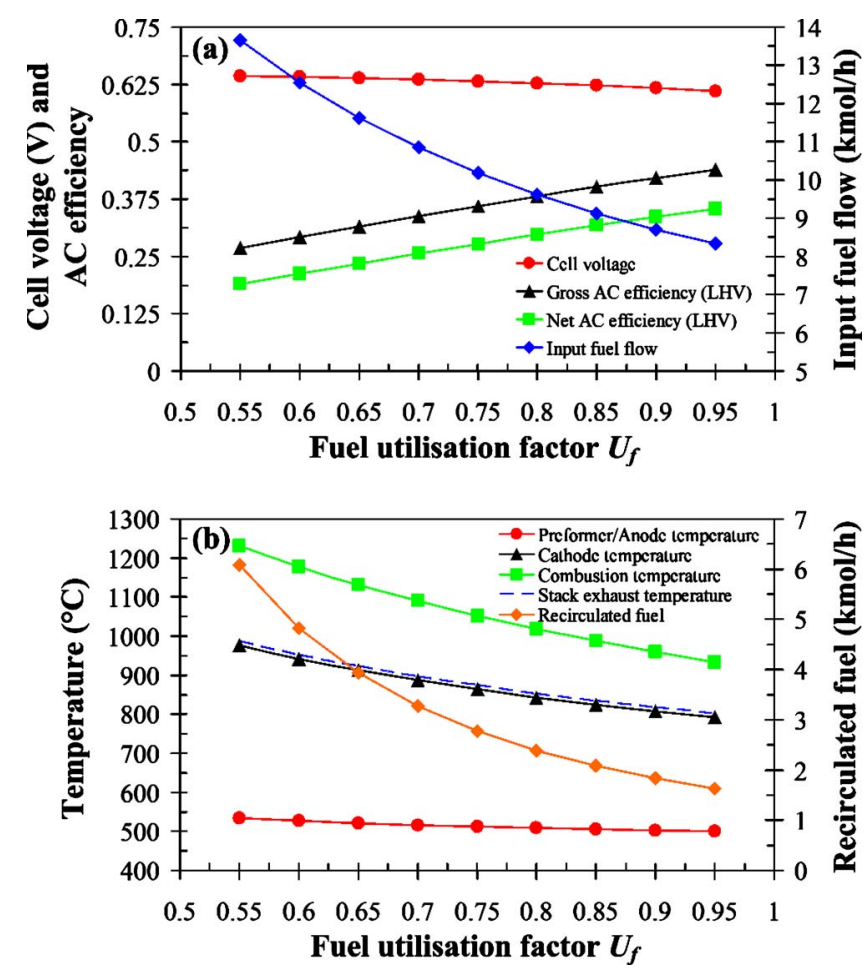

Figure 6. (Color online) Effect of fuel utilization factor for miscanthus fuel on (a) voltage, efficiency, and input fuel flow and (b) pre-reformer/anode temperature, cathode temperature, combustion temperature, stack exhaust temperature, and recirculated fuel.
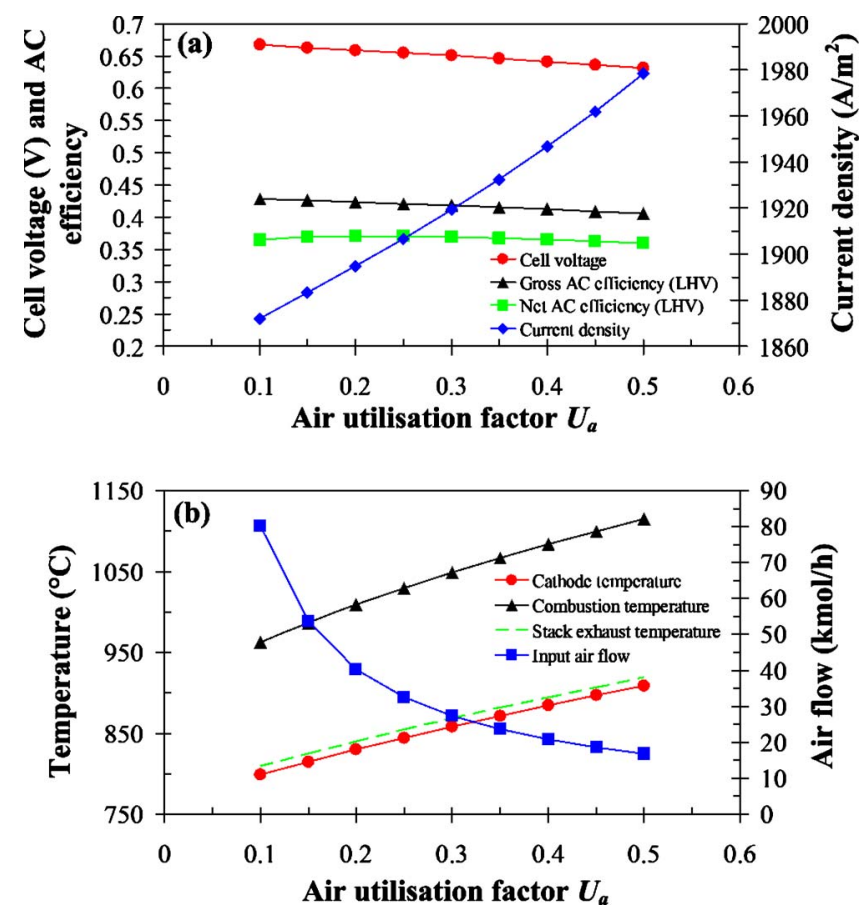

Figure 7. (Color online) Effect of air utilization factor for wood fuel on (a) voltage, efficiency, and current density and (b) cathode temperature, combustion temperature, stack exhaust temperature, and input air flow.

$92.2 \%$ and $0-97 \%$ for wood and miscanthus, respectively). The high temperature and greater amount of steam available promotes the steam reforming of $\mathrm{CH}_{4}$ via Eq. 1. This reaction is endothermic; the forward reaction is favored as temperature increases. Increasing STCR had a negative impact on voltage and efficiency, which was due to the change in the anode temperature and gaseous component partial pressures causing the Nernst voltage to decrease and the voltage losses to rise. It is therefore desirable to operate the stack at low STCR; however, it should be high enough to inhibit carbon formation. Significant carbon deposition is expected for biomass gas at lower temperatures; therefore, steam addition is essential. ${ }^{42}$

Effect of fuel utilization factor.-Figure 6 depicts the influence of $U_{\mathrm{f}}$ on stack performance for miscanthus syngas fuel. The cell voltage decreases with $U_{\mathrm{f}}$ due to increased voltage losses. The input fuel required to achieve the desired power decreases with $U_{\mathrm{f}}$ because more of the fuel energy is converted to electricity rather than heat. Efficiency increases significantly $(\sim 17 \%)$ as a result of the reduced fuel input. The amount of recirculated fuel decreases with $U_{\mathrm{f}}$ as less fuel needs to be recirculated to meet the specified STCR due to the increased $\mathrm{H}_{2} \mathrm{O}$ content in the depleted fuel. As a result of less high temperature depleted fuel being recirculated, the prereformer/anode temperature drops. The cathode and stack exhaust temperatures are dependent on the combustion temperature, which is determined by the amount of fuel available to the combustion plenum. At low $U_{\mathrm{f}}$, more of the fuel is available for combustion; therefore, the temperatures are high, and as $U_{\mathrm{f}}$ increases, the temperatures decrease. The SOFC stack should be operated at high $U_{\mathrm{f}}$ but below the level where the concentration loss increases to a high degree.

Effect of air utilization factor.- The influence of $U_{\mathrm{a}}$ on the system for wood syngas is shown in Fig. 7. The cell voltage and gross efficiency decrease with $U_{\mathrm{a}}$ and the current density increases. The influence of $U_{\mathrm{a}}$ is much less significant than that of $U_{\mathrm{f}}$. The net efficiency rises and reaches a peak value at a $U_{\mathrm{a}}$ of $\sim 20 \%$ and then decreases. For this reason, SOFCs should be operated in the $U_{\text {a }}$ range of $16-20 \%$. As displayed in Fig. $7 \mathrm{~b}$, the stack temperatures 
rise with $U_{\mathrm{a}}$ because at high $U_{\mathrm{a}}$, less air is fed to the stack, which means there is less $\mathrm{N}_{2}$ and excess $\mathrm{O}_{2}$ for cooling in the combustion plenum.

\section{Conclusions}

A model of the SPGI $100 \mathrm{~kW}$ CHP tubular SOFC stack was developed using Aspen Plus. The objective of the work, which was to develop a computer simulation model of a BG-SOFC CHP system capable of predicting system performance under various operating conditions and using diverse fuels, was achieved. The model uses existing Aspen Plus unit operation blocks with minimum requirements for the linking of a subroutine, thus, reducing complexity and ensuring short computational times. It was validated against published data. The effects of varying $j$, STCR, $U_{\mathrm{f}}$, and $U_{\mathrm{a}}$ values on SOFC stack performance were investigated for the stack operating on wood and miscanthus syngas. The results indicate that there must be a trade-off between voltage, efficiency, and power with respect to $j$ and that the stack should be operated at low STCR and high $U_{\mathrm{f}}$. Also, the stack should be operated at a $U_{\mathrm{a}}$ of $\sim 20 \%$. Operation on biomass syngas was compared to natural gas operation and, as expected, performance degrades. Better stack performance was observed for wood syngas compared to miscanthus syngas, the main reason being the higher $\mathrm{H}_{2}$ content of the wood syngas.

The reduction in efficiency seen in syngas operation is attributed to increased required fuel and air input, which is due to the lower quality of the fuel gas and also to decreased power. Even with this performance decrease, the efficiency achieved is much higher than that for traditional biomass systems, making this technology very promising.

Dublin Institute of Technology assisted in meeting the publication costs of this article.

\section{List of Symbols}

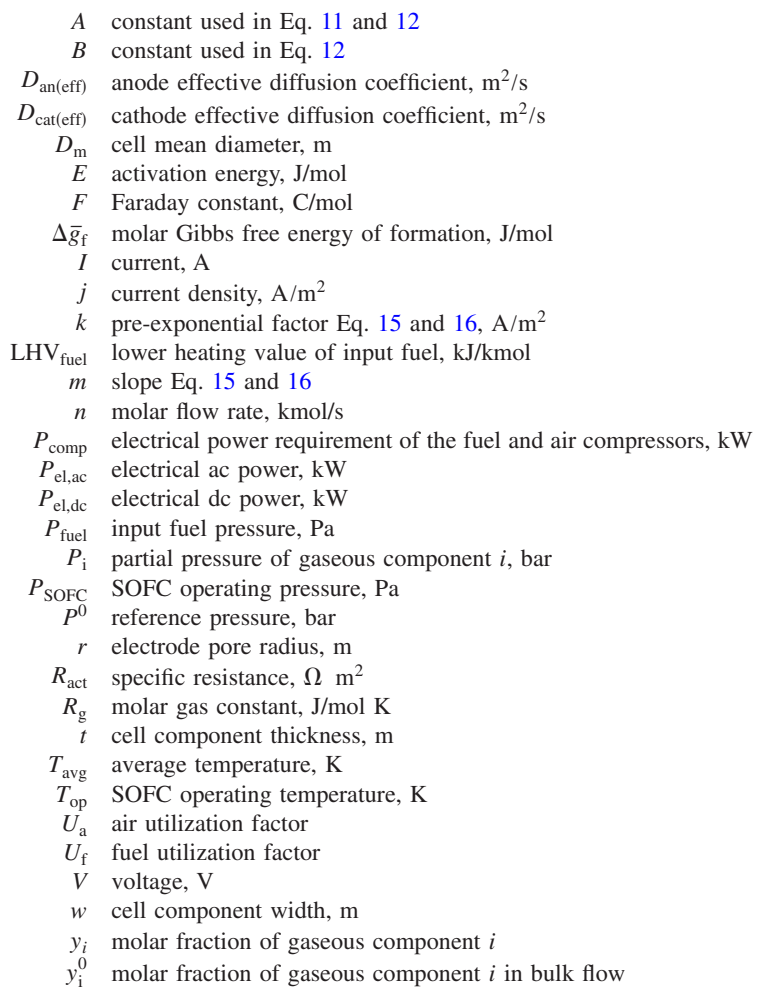

Greek

$$
\begin{aligned}
\delta_{\mathrm{O}_{2}} & \text { constant used in Eq. } 18 \\
\varepsilon & \text { electrode porosity } \\
\eta_{\mathrm{el}, \text { gross }} & \text { gross ac efficiency } \\
\eta_{\mathrm{el}, \text { net }} & \text { net ac efficiency }
\end{aligned}
$$

$\xi$ electrode tortuosity

$\rho$ resistivity, $\Omega \mathrm{m}$

Subscripts

$$
\begin{aligned}
\text { act } & \text { activation } \\
\mathrm{A} & \text { anode } \\
\mathrm{C} & \text { cathode } \\
\text { conc } & \text { concentration } \\
\mathrm{E} & \text { electrolyte } \\
\text { int } & \text { interconnection } \\
\mathrm{N} & \text { Nernst } \\
\mathrm{ohm} & \text { ohmic } \\
\mathrm{i} & \text { gaseous component }
\end{aligned}
$$

\section{References}

1. T. Seitarides, C. Athanasiou, and A. Zabaniotou, Renewable Sustainable Energy Rev., 12, 1251 (2008)

2. S. Cordiner, M. Feola, V. Mulone, and F. Romanelli, Appl. Therm. Eng., 27, 738 (2007).

3. L. Fryda, K. D. Panopoulos, and E. Kakaras, Energy Convers. Manage., 49, 281 (2008).

4. K. D. Panopoulos, L. E. Fryda, J. Karl, S. Poulou, and E. Kakaras, J. Power Sources, 159, 570 (2006).

5. T. Pröll, R. Rauch, C. Aichernig, and H. Hofbauer, in ASME Turbo Expo: Power for Land, Sea, and Air, ASME, p. 103 (2004).

6. M. Sucipta, S. Kimijima, T. W. Song, and K. Suzuki, J. Fuel Cell Sci. Technol., 5, 041006 (2008).

7. M. Sucipta, S. Kimijima, and K. Suzuki, J. Power Sources, 174, 124 (2007).

8. R. Suwanwarangkul, E. Croiset, M. D. Pritzker, M. W. Fowler, P. L. Douglas, and E. Entchev, J. Power Sources, 166, 386 (2007).

9. R. Toonssen, N. Woudstra, and A. H. M. Verkooijen, in The 8th, European Solid Oxide Fuel Cell Forum, The European Fuel Cell Forum, p. 1 (2008).

10. M. Sucipta, S. Kimijima, and K. Suzuki, J. Electrochem. Soc., 155, B258 (2008).

11. G. Schuster, G. Löffler, K. Weigl, and H. Hofbauer, Bioresour. Technol., 77, 71 (2001).

12. W. Doherty, A. Reynolds, and D. Kennedy, Biomass Bioenergy, 33, 1158 (2009).

13. W. Doherty, A. Reynolds, and D. Kennedy, in The 21st International Conference on Efficiency, Cost, Optimization, Simulation, and Environmental Impact of Energy Systems, A. Ziebik, Z. Kolenda, and W. Stanek, Editors, p. 1241 (2008).

14. K. Sasaki, Y. Hori, R. Kikuchi, K. Eguchi, A. Ueno, H. Takeuchi, M. Aizawa, K. Tsujimoto, H. Tajiri, H. Nishikawa, and Y. Uchida, J. Electrochem. Soc., 149 A227 (2002).

15. N. F. Bessette, W. J. Wepfer, and J. Winnick, J. Electrochem. Soc., 142, 3792 (1995).

16. S. Campanari, J. Power Sources, 92, 26 (2001)

17. S. Campanari and P. Iora, J. Power Sources, 132, 113 (2004).

18. A. Bharadwaj, D. H. Archer, and E. S. Rubin, J. Fuel Cell Sci. Technol., 2, 38 (2005)

19. M. Cali, M. G. L. Santarelli, and P. Leone, Int. J. Hydrogen Energy, 32, 343 (2007).

20. A. Hirano, M. Suzuki, and M. Ippommatsu, J. Electrochem. Soc., 139, 2744 (1992).

21. P.-W. Li and K. Suzuki, J. Electrochem. Soc., 151, A548 (2004).

22. P. Leone, M. Santarelli, and M. Cali, ECS Trans., 5(1), 553 (2007).

23. S. Kakaç, A. Pramuanjaroenkij, and X. Y. Zhou, Int. J. Hydrogen Energy, 32, 761 (2007).

24. W. Zhang, E. Croiset, P. L. Douglas, M. W. Fowler, and E. Entchev, Energy Convers. Manage., 46, 181 (2005).

25. M. Siedlecki, K. d. Nat, E. Simeone, and W. d. Jong, in World Renewable Energy Congress IX, WREC/WREN (2006).

26. T. Pröll, Vienna University of Technology, Vienna, Austria Private Communication (2008).

27. M. Siedlecki, Delft University of Technology, Delft, The Netherlands, Private communication (2009).

28. M. Gariglio, M. Santarelli, F. De Benedictis, M. Cali, G. Orsello, and G. Disegna, ECS Trans., 12(1), 419 (2008).

29. T. W. Song, J. L. Sohn, J. H. Kim, T. S. Kim, S. T. Ro, and K. Suzuki, J. Power Sources, 142, 30 (2005).

30. T. W. Song, J. L. Sohn, T. S. Kim, and S. T. Ro, J. Power Sources, 158, 361 (2006).

31. M. Sucipta, S. Kimijima, and K. Suzuki, ECS Trans., 7(1), 1781 (2007).

32. Y. Komatsu, S. Kimijima, and J. S. Szmyd, ECS Trans., 25(2), 1061 (2009).

33. Y. Komatsu, S. Kimijima, and J. S. Szmyd, Energy 35, 9822010.

34. S. C. Singhal, Solid State Ionics, 135, 305 (2000).

35. M. C. Williams, J. P. Strakey, and S. C. Singhal, J. Power Sources, 131, 79 (2004).

36. E. Achenbach, J. Power Sources, 49, 333 (1994).

37. S. H. Chan, K. A. Khor, and Z. T. Xia, J. Power Sources, 93, 130 (2001).

38. F. Calise, M. D. d'Accadia, A. Palombo, and L. Vanoli, J. Fuel Cell Sci. Technol., 5, 021014 (2008)

39. E. N. Fuller, P. D. Schettler, and J. C. Giddings, Ind. Eng. Chem., 58, 19 (1966).

40. P. Costamagna and K. Honegger, J. Electrochem. Soc., 145, 3995 (1998).

41. See supplementary material at http://dx.doi.org/10.1149/1.3407524 (E-JESOAN157-003007) for additional information.

42. K. Sasaki and Y. Teraoka, J. Electrochem. Soc., 150, A878 (2003). 